\title{
The Role of Firm Characteristics in Voluntary Disclosure of IC Information and Its Importance for High-Tech Companies
}

Ana Rep

Faculty of Economics and Business

University of Zagreb, Zagreb, Croatia

Katarina Žager

Faculty of Economics and Business

University of Zagreb, Zagreb, Croatia

Cidália Oliveira

School of Economics and Management (NIPE)

University of Minho, Braga, Portugal arep@efzg.hr

kzager@efzg.hr

cidalia.oliveira@eeg.uminho.pt

\begin{abstract}
The purpose of this paper is to analyse whether the extent and quality of voluntarily disclosed information regarding intellectual capital (IC) are correlated with certain characteristics of a company. IC is very important for IT companies. Therefore, financial and non-financial statements of 32 high-tech companies were investigated using the content analysis method. To test the influence of firm characteristics on the intellectual capital disclosure index (ICDI), the regression model was used. The size of the firm was the only independent variable that has had a statistically significant influence on the ICDI. The auditor type, as well as financial ratios, have not shown a statistically significant influence on the extent and quality of IC disclosures. This study reflects the state regarding the voluntary IC disclosures in Croatia and therefore the study may be a roadmap for further research and, more importantly, might promote awareness of the importance of transparent reporting.
\end{abstract}

Keywords: High-Tech Companies, Intellectual Capital, Voluntary Disclosure, Transparent Reporting

\section{Introduction}

Today, more than ever, every kind of business is influenced by a new way of thinking and acting. The rapid development of information communication technology (ICT) affects business in all of its segments. Traditional ways of thinking and acting have been replaced by modern ones. In that context, intangible asset (IA) has become an inevitable part of the firm resources, making a huge impact on the firm's value. IAs are considered to be just a part of the general term intellectual capital (IC), since IC implies a wider spectrum in relation to IAs, as defined by accounting standards. 
Generally, intangibles, IAs, and IC are often used interchangeably with the same general meaning. There are various definitions of IC which exist in literature. Edvinsson, Malone and Brooking, the pioneers when it comes to IC, have a similar but a bit different view on the IC components. According to Brooking, IC divides into human-centered assets, infrastructure assets, intellectual property assets, and market assets, while Edvinsson and Malone have divided IC into human capital, structural capital (organizational, process, and innovation capital), and customer capital [1]. Sullivan [2] has summarized the several definitions of IC, as defined by the pioneers into the field of knowledge creation: "Hubert Saint-Onge defines knowledge capital as the sum of human capital (the capabilities of the individuals required to provide solutions to customers); customer capital (the depth, width, attachment, and profitability of the franchise); and structural capital (the organizational capabilities of the organization to meet market requirements); Leif Edvinson of Skandia defines it as "the sum of the firm's human and structural capital."; and Tom Stewart of Fortune magazine defines IC as "the intangible assets of skill, knowledge, and information." As defined by Larry Prusak, IC is "intellectual material that has been formalized, captured, and leveraged to produce higher-valued assets [3]." Bounfour and Edvinson [4] state that "at the corporate level, intangible investments (research and development or R\&D, innovation, knowledge creation and fertilization, marketing and advertising expenditures) are now unanimously considered the most important sources of performance." "The intellectual capital (IC) held by a firm can be thought of as a form of 'unaccounted capital' within the traditional accounting system... described as the knowledge-based equity that supports the knowledge-based assets of a firm [5]." According to the words of Choo and Bontis [6] "as long as the economic forces embrace new knowledge-intensive industries, the field of intellectual capital will have an important place in the minds of academics and practitioners". Although their statement was issued almost two decades ago, it is still valid today.

There are many academics and practitioners whose interest is devoted to IC management, measurement, recording, and reporting. Studies and researches concerning IC can be divided into those which examine the measurement of IC [1], [7] - [19], the ones which investigate the correlation between intellectual capital disclosure (ICD) and financial performance of a company [20] - [27], and the ones which investigate the correlation between ICD and firm characteristics (namely company size, cost of equity capital, market capitalization or industry type) [28] [33].

A research conducted by Rep [34] has shown that computer programming companies in Croatia underestimate the value of IAs. To widen the research, the main goal of this study is to investigate whether Croatian high-tech companies report a nonfinancial information regarding their IC not present on the balance sheet and which firm characteristics relate to the disclosures. In that context, the empirical research sought a connection between the depth of the disclosed information about the firm's IC and the firm's characteristics, namely firm size, auditor type, profitability, liquidity, leverage, activity, and economy. A content analysis of the non-financial reports was conducted, followed by testing the hypothesis using the regression analysis model. The paper is based on the assumption that voluntary financial as well 
as non-financial information regarding IC is at a low level. Some authors have already proved that companies in the high technology industry do not disclose additional information regarding IC [31], [33].

The research results regarding the measurement and reporting on IC could be useful for managers and other decision makers, accountants, and standard setters. Practitioners could improve their reporting policies by filling gaps that the research found and, by doing so, upgrade their relations with business partners and other interested stakeholders. They could improve their overall business by monitoring the set goals and strategy. Besides the empirical research, a possible way of reporting on and tracking IC was proposed in terms of Balanced Scorecard (BSC) with the possibilities it provides.

The introduction is followed by the theoretical part which deals with accounting, as well as alternative methods for measuring the value of the IC. The next chapter is related to the hypothesis development followed by the empirical research and the results. The last part suggests some ways of improving the measurement, recording, and reporting about the IC value in terms of the BSC.

\section{The Impact of Intangible Assets Measurement on the Value of a Company and Its Performance}

IC consists of human capital, structural capital, and relational capital, but it may be divided into other ways depending on the company's structure. Although it is about intangibles, IC has its value which is, in many cases, crucial for the continuation of the business. Companies should put an effort to present that value to the stakeholders in additional disclosures since most of it is not presented in financial statements. "Voluntary disclosure is especially important in the knowledge based company where substantial amounts of money are invested in intangible assets, which are not fully recognized on the financial statements [35]." Most companies dealing with services or high technology products cannot operate without their employees, whose knowledge is crucial for developing new services, technologies or other products. On the other hand, that value is not presented on the balance sheet because there is no generally accepted method for measuring the value of employees' knowledge. Based on that, the value of human capital is not considered a part of IAs. The International Accounting Standards/International Financial Reporting Standards (IASs/IFRSs) prescribe the accounting treatment for all types of assets presented on the balance sheet. Accordingly, the methods for initial and subsequent measurement, as well as requirements for recognition and unrecognition of the IAs are prescribed under the IAS 38 - Intangible assets.

\subsection{Accounting Methods for Measuring Intangible Assets Value}

When it comes to the accounting treatment of IC there are two types of intangibles: IA recognized on the balance sheet under the long-term IAs and intangibles not recognized on the balance sheet. "Market-value of most public companies is considerably higher than their corresponding book-value, which represents only the 
tangible assets of the firm [36]." "Entities frequently expend resources, or incur liabilities, on the acquisition, development, maintenance or enhancement of intangible resources such as scientific or technical knowledge, design, and implementation of new processes or systems, licenses, intellectual property, market knowledge and trademarks (including brand names and publishing titles). Common examples of items encompassed by these broad headings are computer software, patents, copyrights, motion picture films, customer lists, mortgage servicing rights, fishing licenses, import quotas, franchises, customer or supplier relationships, customer loyalty, market share and marketing rights [37]." In addition, the IAS 38 [37] states that not all of the above-mentioned items meet the definition of an IA. An item has to meet several criteria to be recognized as an IA: it has to be identifiable (is separable and/or arises from contractual or other legal rights), an entity has to have control over the item, and future economic benefits arising from the asset have to be expected to flow into the entity. In addition, Bhasin proposes that "the relationship between Intellectual Capital and Market Value, in equation form, can be stated as:

Market Value (MV) = Book Value (BV) + Intellectual Capital (IC) [36]".

Development expenditures, concessions, patents, licenses, trademarks and service marks, software, goodwill, and prepayments for the acquisition of intangible assets can be recognized under the long-term IAs on the balance sheet since there are generally accepted measurement methods for such items. Besides, all of these items meet the criteria for the recognition of an item as an IA, as prescribed under the IAS 38:

a) "the item meets the definition of an intangible asset; and

b) the recognition criteria [37]."

Furthermore, "an intangible asset shall be recognized if, and only if:

a) it is probable that the expected future economic benefits that are attributable to the asset will flow to the entity; and

b) the cost of the asset can be measured reliably [37]."

According to the IAS 38, "an intangible asset shall be measured initially at cost [37]." Nonetheless, apart from a separately purchased IA, it may also be acquired in a business combination, by way of a government grant (free of charge), in an exchange of assets or internally generated. IAS 38 prescribes that "internally generated goodwill shall not be recognized as an asset [37]." It states that "internally generated goodwill is not recognized as an asset because it is not an identifiable resource (i.e. it is not separable nor does it arise from contractual or other legal rights) controlled by the entity that can be measured reliably at cost [37]." On the other hand, an internally generated IA may be recognized if it is identifiable, whether and when the asset will generate future economic benefits, and if the costs related to the asset may be determined reliably. "To assess whether an internally generated intangible asset meets the criteria for recognition, an entity classifies the generation of the asset into:

a) a research phase; and

b) a development phase [37]."

In the research phase, all costs incurred have to be recognized as expenses of the period in which they were incurred and an entity cannot recognize it as an internally generated IA since future economic benefits are not certain to flow into the entity. On 
the other hand, the entity can recognize internally generated IA arising from the development phase, "if, and only if, an entity can demonstrate all of the following:

a) the technical feasibility of completing the intangible asset so that it will be available for use or sale;

b) its intention to complete the intangible asset and use or sell it;

c) its ability to use or sell the intangible asset;

d) how the intangible asset will generate probable future economic benefits;

e) the availability of adequate technical, financial and other resources to complete the development and to use or sell the intangible asset;

f) its ability to measure reliably the expenditure attributable to the intangible asset during its development [37]."

Internally generated IA is initially recognized at cost. "The cost of an internally generated intangible asset comprises all directly attributable costs necessary to create, produce, and prepare the asset to be capable of operating in the manner intended by management [37]." All costs incurred in the research phase have to be classified as expenses, which decrease the profit. Those costs may be significant in high technology, pharmaceutical, and similar industries. The financial result of these companies decreases in the years when they conduct research and that could negatively influence investments in these companies. To avoid that, additional information regarding any research activities, in both financial and non-financial terms, should be disclosed in one of the non-financial reports.

After the initial recognition of the IA, either the cost or the revaluation model needs to be carried out. If the cost model is carried out for an IA, then the cost will be increased for any accumulated amortization and any accumulated impairment losses. On the other hand, if the revaluation model is carried out for an IA, then its revalued amount ("being its fair value at the date of the revaluation less any subsequent accumulated amortization and any subsequent accumulated impairment losses [37]') is taken into consideration.

Similar to tangible assets, an entity, namely its board members or managers, have to assess whether an IA has finite or indefinite useful life [38]. If an IA has a finite useful life, an entity has to assess the number of years of the useful life or the number of products or similar units in the useful life. Croatian Profit Tax Act [39] prescribes that companies may use the amortization rate for IAs of $25 \%$ and computer software of $50 \%$. These amortization rates may be doubled for tax purposes. Accordingly, IAs and computer software are usually written off between one and four years. Most companies use the same amortization rates for accounting purposes, as well as for tax purposes, what results in firms undervaluing the IA presented on the balance sheet. It is not uncommon for companies to present the IAs on the balance sheet as having no value despite using it in its business. In addition to the IAs being used but already amortized at the full amount, there is also IAs which cannot be recognized on the balance sheet at all since there is no generally accepted method for measuring their value. 


\subsection{Alternative Methods for Measuring the Value of Intellectual Capital}

An IA, which does not meet the definition of an IA and the recognition criteria, cannot be presented on the balance sheet under the heading of IAs. "Expenditure on internally generated brands, mastheads, publishing titles, customer lists, and items similar in substance cannot be distinguished from the cost of developing the business as a whole and therefore such items are not recognized as intangible assets [37]" but are presented under the expenses in the period in which they incurred. Accordingly, internally generated goodwill is not a part of an IA according to accounting standards. There is an option to disclose such information in the notes to financial statements, but previous researchers have found that disclosures regarding tangible and intangible assets in Croatia are at a low level when it comes to the notes to financial statements [39]. Scientists and practitioners are aware that it may have a negative or unrealistic influence on profitability, return rates, and overall business results. Based on that, companies are encouraged to present non-financial information either through the notes to financial statements or through other reports such as annual report, nonfinancial report, integrated report or BSC.

\section{Category of measurement approach}

Direct Intellectual Capital methods (DIC)

\section{Market \\ Capitalization \\ Methods (MCM)}

Return on Assets methods (ROA)

Scorecard Methods (SC)

\section{Description}

Estimate the $\$$-value of intangible assets by identifying its various components. Once these components are identified, they can be directly evaluated, either individually or as an aggregated coefficient.

Calculate the difference between a company's market capitalization and its stockholders' equity as the value of its intellectual capital or intangible assets.

Average pre-tax earnings of a company for a period of time are divided by the average tangible assets of the company. The result is a company ROA that is then compared with its industry average. The difference is multiplied by the company's average tangible assets to calculate an average annual earning from the Intangibles. Dividing the above-average earnings by the company's average cost of capital or an interest rate, one can derive an estimate of the value of its intangible assets or intellectual capital.

The various components of intangible assets or intellectual capital are identified, and indicators and indices are generated and reported in scorecards or as graphs. SC methods are similar to DIC methods, expect that no estimate is made of the $\$$ - value of the Intangible assets. A composite index may or may not be produced.

Table 1. Four approaches for measuring intangibles Source: Sveiby [41]; according to Luthy, 1998 and Williams, 2000

To evaluate the IA that is not part of the company's assets presented on the balance sheet, several methods and models for measuring and managing IC have been developed. "The suggested measuring approaches for intangibles fall into at least four 
categories of measurements approaches [41]." Table 1 presents these four categories for which Sveiby said that are "an extension of the classifications suggested by Luthy (1998) and Williams (2000) [41]."

However, there is no generally accepted measurement method for measuring employees' knowledge, knowledge management, know-how, customer lists, mailing lists of clients, brand names, firm procedures, and strategies. Such IAs are not recognized on the balance sheet although they increase the market value of the firm and, unfortunately, are usually not disclosed through the general purpose financial statements. Therefore, firms are encouraged to disclose such non-financial information in other non-financial reports. Such information is a valuable resource for firm stakeholders and first-line investors. "Harmonization through EU legal Directives requires compliance and appropriate compliance mechanisms if harmonization is to be achieved in practice. There is no doubt that the EU Directives have been successful in bringing all community companies up to a reasonable level of disclosure, but improvements in levels of disclosure need to incentivized and compliance mechanisms upgraded [42]." In addition to external reports, firms also prepare internal reports. The BSC has been recognized as a powerful tool for reporting and measuring the IAs, as well as the firm's set goals and strategy. Many studies have proven that firms, which prepare additional reports and disclose additional information make better results in terms of profitability [43] - [45] since higher profitability makes the management motivated to disclose additional information and attract new investors.

\section{Hypothesis Development}

Various authors have tested how different variables influence the level of voluntary disclosures regarding the IC. The next subheadings present the foundation for hypothesis development.

\section{1. $\quad$ Firm Size}

There is a general assumption that larger firms make detailed disclosures. Many researchers have analysed the influence of the firm size on the level of voluntary ICD. The size of firms listed in the Italian Stock Exchange significantly affects the ICD [29]. Guthrie et al. [46] found that firm size has a significant influence on the overall disclosure index in both Australian and Hong Kong firms. They defined the size of firms as follows: "Large companies were those whose market capital scored above the median, while small companies were those whose market capital scored below the median [46]." A high level of relationship $(\mathrm{p}<0,000)$ between firm size and voluntary ICD was found by White et al. [47] on a sample size of 96 Australian listed biotechnology companies. Bruggen et al. [35] found that firm size is a determinant for ICD, too. They researched 125 publicly listed Australian firms. Unlike the abovementioned studies, Bellora and Guenther [48] carried out their research by taking into account only a part of ICD (namely innovation capital). "Innovation capital (INC) is that part of the intellectual capital of a firm that describes the ability of a firm to 
generate and use innovative solutions, and related results in terms of intellectual property rights and other tangible, intangible and financial assets [Edvinsson and Malone, in [48]. Regardless, they found "a significant difference $(p<0.1)$ in the quantity of disclosure between smaller and larger firms [48]."

On the other hand, some studies found that firm size was not determinant of ICD. "Contrary to expectations, and findings from prior literature, none of the coefficients related to organizational size and physical capital performance were statistically significant in any of the regression [49]." Bukh et al. [50], who had analysed Danish IPO prospectuses found no correlation between firm size and the amount of voluntary ICD, too. The same result had been derived by Rimmel et al. [51] on the sample of Japanese IPO prospectuses. Regardless of these results, the first hypothesis has been set as follows:

H1. There is a positive correlation between firm size and voluntary ICD.

\subsection{Audit Firm Type}

"The former Big Six audit firms could maintain independence from their clients" demands for limited disclosure more easily than smaller audit firms as they had a reputation to uphold [Chow and Wong-Boren, in [52]", while it is more important to meet the requirements of the clients to continue the cooperation from the perspective of smaller audit firms. In addition to that statement, correlation and regression analysis conducted by the Whiting and Woodcock [52] demonstrated that companies audited by the Big Four auditing firms show more extensive ICD than those which financial statements are audited by other audit firms. The same results had been presented by Ferreira et al. [53] on the sample of annual reports of Portuguese listed companies. Based on the reputation of the Big Four audit firms, the hypothesis has been set as follows:

H2. There is a positive correlation between auditor type and voluntary ICD.

\subsection{Financial Ratios}

Previous studies had tested whether firm performance or profitability influences the disclosure level. The results of the study that had been conducted by Abdolmohammadi [30] on a sample of Fortune 500 companies showed that greater profitability (measured as a difference between average industry ROA and firm's ROA) results in a greater ICD. Depoers and Jeanjean confirmed the hypothesis that "the higher the firm performance, the less the firms withhold information [54]." Thus, their results have shown that "good news firms seek to highlight their good performance by making the voluntary disclosures comparable from one year to the next [54]." On the other hand, Lim et al. [55] had not found any significant influence of ROA on ICD quality and ICD frequency. Since more studies had proven a positive correlation between a firm's profitability and ICD level, the third hypothesis is therefore:

H3. There is a positive correlation between firm's profitability and voluntary ICD. 
One of the most frequently used ratios in the analysis of financial statements is firm liquidity, measured as current assets to current liabilities. A study conducted by Olusegun Wallace et al. [45] showed that overall disclosure decreases with the increase of the firm liquidity. Contrary to that, Barako [56] found a significant positive correlation between firm liquidity and some categories of disclosure. Even though the research results are not uniform, the fourth hypothesis assumes a positive correlation:

H4. There is a positive correlation between firm liquidity and voluntary ICD.

"Higher leveraged companies are usually subject to higher demands for information from creditors and shareholders than the lower leveraged ones, inducing these companies to disclose more information [Camfferman and Cooke, in [35]. A positive correlation between ICD and leverage, measured as total debt to total asset, had been found by Boujelbene and Affes [32], even though the correlation was not significant. On the other hand, Brüggen et al. [35] found a negative, but insignificant relationship between ICD and leverage. No relationship between ICD and leverage was also detected by Ferreira et al. [53]. Despite mixed results, the authors have assumed that the more leveraged companies do not disclose more information compared to the companies financed mostly by their capital:

H5. There is a negative correlation between firm leverage and voluntary ICD.

Besides the main independent variables, two control variables were also included in the regression model. The first additional independent variable was the total asset turnover ratio as one of the activity ratios used in the analysis of financial statements. The higher the ratio is, the higher the firm's revenues are, compared to its total assets. Another ratio used as the second control independent variable was the total economy ratio, measured as total revenues to total expenses.

\section{Empirical Research on the Sample of High-Tech Enterprises}

\subsection{Structure of the Research Sample and Methodology}

The research was carried out with the intention of gaining insight into the influence of firm characteristics on voluntary reporting regarding the IC. The goal of the study was to investigate the existence of additional information disclosure regarding the IC. The empirical research was carried out by employing the content analysis method. "IC has greater importance for software and information technology companies as the skill sets of their staff plays a crucial role in successful operations [31]." Accordingly, the non-financial statements of high-tech companies were investigated. The investigated statements included annual reports, sustainability reports, integrated reports, and other non-financial reports. Using the descriptive statistic and inferential statistics tests, results are interpreted in the next section. The research sample included high-tech firms registered in Croatia since they might have a great value of IC that is not presented under the heading of long-term IAs on their balance sheet. The selection was made based on six types of activities (communication equipment production, motor vehicles production, computer programming, computer consultancy, computer equipment and system management, and data processing, hosting and related 
activities) selecting the companies with the highest overall revenues. All of the selected types of activities are considered belonging to high-tech activities since their outcomes are high technology products and IT services.

\subsection{Defining the Variables}

The intellectual capital disclosure index (ICDI) presents the dependent variable in the regression model. It has been structured based on the frameworks of previous studies and contains 25 items. Numerous researchers had used frameworks compiled and tested by Sveiby [57] and Guthrie and Petty [58] with slight modifications ([29], [30], [46], [47], [50], [52], [55] [59] - [61]). The same approach has been applied in this research. The modified ICDI is presented in table 2.

\begin{tabular}{|c|c|c|c|}
\hline \multirow{14}{*}{$\begin{array}{c}\text { Internal } \\
\text { capital/ } \\
\text { Organizational } \\
\text { capital/ } \\
\text { Structural } \\
\text { capital }\end{array}$} & $\begin{array}{c}\text { Intellectual property: } \\
\text { Patents, copyrights, } \\
\text { trademarks }\end{array}$ & 1) & Explanation of financial categories \\
\hline & \multirow{2}{*}{$\begin{array}{l}\text { Management } \\
\text { philosophy }\end{array}$} & 2) & Statements of mission and vision \\
\hline & & 3) & Statements of business model and strategy \\
\hline & Corporate culture & 4) & $\begin{array}{l}\text { Attitudes, experiences, beliefs and values } \\
\text { of the company }\end{array}$ \\
\hline & Management processes & 5) & $\begin{array}{l}\text { Description of processes within the } \\
\text { company }\end{array}$ \\
\hline & \multirow{3}{*}{ Information systems } & 6) & Description of current IT systems \\
\hline & & 7) & Description of investments in IT \\
\hline & & 8) & $\begin{array}{l}\text { Research and development activities } \\
\text { regarding own developed systems }\end{array}$ \\
\hline & Networking systems & 9) & $\begin{array}{l}\text { Means and processes used for the } \\
\text { communication and networking }\end{array}$ \\
\hline & \multirow{3}{*}{ Financial relations } & 10) & Cost of equity, interest rates \\
\hline & & 11) & ROA, ROE \\
\hline & & 12) & Methods used for IC measurement \\
\hline & \multirow[b]{2}{*}{ Sustainability concerns } & 13) & Care about the environment \\
\hline & & 14) & $\begin{array}{l}\text { Description of involvement in the } \\
\text { community }\end{array}$ \\
\hline \multirow{5}{*}{$\begin{array}{l}\text { External } \\
\text { capital/ } \\
\text { Relational } \\
\text { capital }\end{array}$} & Brands & 15) & $\begin{array}{l}\text { List and description of brands and/or main } \\
\text { products }\end{array}$ \\
\hline & \multirow[b]{2}{*}{ Customers } & 16) & Key customers \\
\hline & & 17) & $\begin{array}{l}\text { Market share breakdown } \\
\text { country/segment/product }\end{array}$ \\
\hline & Customers loyalty & 18) & Indicators of customer satisfaction \\
\hline & Business partners & 19) & Main suppliers and/or distribution channels \\
\hline
\end{tabular}




\begin{tabular}{|c|c|c|}
\hline & $\begin{array}{l}\text { Agreements and } \\
\text { contracts }\end{array}$ & $\begin{array}{l}\text { 20) Licensees and franchises held by the } \\
\text { company }\end{array}$ \\
\hline \multirow{5}{*}{ Human capital } & Know-how & 21) Employees knowledge and competencies \\
\hline & \multirow{3}{*}{ Education/training } & $\begin{array}{l}\text { 22) Description of development programs and } \\
\text { activities }\end{array}$ \\
\hline & & 23) Education and training expenses \\
\hline & & $\begin{array}{l}\text { 24) Number of employees involved in the } \\
\text { education programs and/or hours per } \\
\text { employee }\end{array}$ \\
\hline & Satisfaction & 25) Employee interviews and/or questionnaires \\
\hline
\end{tabular}

Table 2. Intellectual capital disclosure index: categorical items with explanations Source: Adopted from Guthrie and Petty [58], Bukh et al. [50], and Schneider and Samkin $[62]$ and modified by the authors

The ICDI items have been measured using a dummy variable for each item (using code 1 if an item was disclosed and 0 if not). The formula used for calculating the overall index for each company is:

$$
\text { ICDI }=\frac{\sum_{\mathrm{i}=1}^{\mathrm{m}} \mathrm{d}_{\mathrm{i}}}{\mathrm{m}}
$$

where "i" stands for each item from ICDI, "m" stands for the maximum possible score of each company (25), and "di" equals 1 if an item was disclosed or 0 if not.

Independent variables have been divided into continuous and dummy variables. Table 3 summarizes the employed independent variables measurement methods.

\begin{tabular}{cc}
\hline Independent variables & Measurement \\
\hline Continuous variables & Total revenues; Total assets; Category: $1=$ \\
Size (SIZE) & small, $2=$ medium, $3=$ large company \\
Net income / Equity \\
Profitability (ROE) & Current assets / Current liabilities \\
Liquidity (LIQUID) & Total liabilities / Total assets \\
Leverage (LEVER) & Total revenues / Total assets \\
Activity (ACTIVE) & Total revenues / Total expenses \\
Economy (ECONOMY) & \\
Dummy variable & $1=$ Big 4, $0=$ non Big 4 \\
Auditor type (AUDIT) &
\end{tabular}

Table 3. Independent variables measurement Source: authors' presentation, according to Žager et al. [63]

Recent studies have been explaining the size variable either as an amount of turnover or as a value of total assets. This study has taken into account both approaches. To 
compare these results with the exact category to which each company belongs, an additional test has been performed which takes into account the category to which the company belongs, namely small, medium-sized or large company.

\subsection{Defining the Model}

The model has been set as follows:

$$
\begin{gathered}
I C D I_{i}=\alpha+\beta_{1} \operatorname{SIZE}_{i}+\beta_{2} A_{U D I T_{i}}+\beta_{3} \text { ROE }_{i}+\beta_{4} L_{I Q U I D_{i}-} \\
\beta_{5} \text { LEVER }_{i}+\beta_{6} A C T I V E_{i}+\beta_{7} \text { ECONOMY } \varepsilon_{i}
\end{gathered}
$$

After running the initial model, a problem occurred regarding the abnormal distribution of residuals (Jarque-Bera 7,33; p-value 0,026). To solve that problem, various amendments had been applied. Finally, one company had to be dropped from the model since it was considered an outlier. This was the company which disclosed the maximum number of investigated items $(80 \%)$. The final model had been run three times, each time with the different size variable already explained above.

\section{Research Results}

\subsection{Content Analysis Findings}

Table 4 presents the general, as well as the partial disclosure results regarding the ICDI of all 32 companies from the research sample.

\begin{tabular}{l|rrrr}
\hline & \multicolumn{1}{|c}{$\begin{array}{c}\text { Overall } \\
\text { index }\end{array}$} & $\begin{array}{c}\text { Internal } \\
\text { Capital }\end{array}$ & $\begin{array}{c}\text { External } \\
\text { Capital }\end{array}$ & \multicolumn{1}{c}{$\begin{array}{c}\text { Human } \\
\text { Capital }\end{array}$} \\
\hline Mean & 0,1900 & 0,2232 & 0,1875 & 0,1000 \\
Median & 0,1250 & 0,1719 & 0,1719 & 0,0938 \\
Mode & 0,0938 & 0,0938 & 0,3750 & 0,1250 \\
Standard & 0,1578 & 0,1746 & 0,1689 & 0,0261 \\
Deviation & & & & \\
Variance & 0,8304 & 0,7821 & 0,9006 & 0,2615 \\
Coefficient & 0,0000 & 0,0000 & 0,0000 & 0,0625 \\
Minimum & 0,7188 & 0,7188 & 0,3750 & 0,1250 \\
Maximum & 152 & 100 & 36 & 16 \\
Sum & 800 & 448 & 192 & 160 \\
Max possible & 25 & 14 & 6 & 5 \\
Items Count & & & &
\end{tabular}

Table 4. Descriptive statistics of disclosure index

Source: authors' calculation 
The results have shown that all companies had disclosed $19 \%$ of their overall ICDI on average. The low level of disclosures regarding the IC is consistent with other studies which had a sample of high-tech companies ([31], [33], [64]). The low percentage of disclosures means that Croatian high-tech companies are not aware enough of the importance of the ICD to stakeholders. The mitigating circumstance to this result could be that the Croatian market is not as capital oriented as other markets. In addition, the Croatian economy is primarily characterized by a bank-oriented financial system, and companies which were part of the research were mostly privately funded (only three companies were listed on the Zagreb Stock Exchange). However, many of these companies are trying to attract investments and therefore should put much more attention to disclosing information not presented in other financial statements. The companies had disclosed the most information regarding internal capital $(22,32 \%$ on average) and the least information regarding human capital (only $10 \%$ on average). The median values show even worse results. Variance coefficient shows that there are very significant differences between each company, going from $26,15 \%$ for human capital to $90,06 \%$ for external capital. These results show the highest and lowest numbers, as well as the average number of items disclosed by each company. The number of items disclosed by companies is presented in table 5 .

\begin{tabular}{lccccc}
\hline Number of items disclosed & $0-5$ & $6-10$ & $11-15$ & $16-20$ & $21-25$ \\
Number of companies & 24 & 4 & 3 & 1 & 0 \\
\hline
\end{tabular}

Table 5. Distribution of items disclosed

Source: authors' calculation

There are three companies which did not disclose any of the investigated information and six which disclosed only one item. It is concerning that $75 \%$ of the companies had disclosed up to 5 items (20\%) from the ICDI. Median for the overall index disclosed in table 4 says that $50 \%$ of the companies disclosed up to $12,5 \%$ of all investigated information, while the rest $50 \%$ disclosed more than $12,5 \%$.

\subsection{Regression Model Results}

To test the influence of independent variables (firm characteristics) on the ICDI, the regression model using the Ordinary Least Squares (OLS) method had been employed. After running the initial model with 31 companies, all of the financial ratios, as well as auditor type did not show any statistically significant influence. Even though these results were not expected for all of the ratios, they are consistent with many others (see e.g. [32], [35], [53], [55]). However, the results were the most surprising for profitability measured as return on equity, which showed a negative influence, while it had had a significant positive influence in most prior studies (see e.g. [20], [30], [54]). Regarding that, two financial ratios, total asset turnover ratio and total economy ratio, initially included as control variables, had been excluded from 
the model. This improved the explanatory power of the model (from R2 $=56,9 \%$ to $\mathrm{R} 2=59,53 \%$ ). The results of the final regression model are presented in table 6 .

Dependent Variable: ICDI

Method: Least Squares

Included observations: 31

\begin{tabular}{crlrr}
\hline \hline \multicolumn{1}{c}{ Variable } & Coefficient & \multicolumn{1}{c}{ Std. Error } & t-Statistic & Prob. \\
\hline \hline C & -0.384366 & 0.101095 & -3.802014 & 0.0008 \\
SIZE & 0.229562 & 0.034689 & 6.617730 & 0.0000 \\
AUDIT & 0.034120 & 0.037971 & 0.898592 & 0.3774 \\
ROE & -0.010598 & 0.018158 & -0.583642 & 0.5647 \\
LIQUID & 0.005665 & 0.008661 & 0.654022 & 0.5191 \\
LEVER & 0.080245 & 0.086937 & 0.923026 & 0.3648 \\
\hline \hline R-squared & 0.662783 & Mean dependent var & 0.170323 \\
Adjusted R-squared & 0.595339 & S.D. dependent var & & 0.156960 \\
S.E. of regression & 0.099847 & Akaike info criterion & -1.598367 \\
Sum squared resid & 0.249236 & Schwarz criterion & -1.320821 \\
Log likelihood & 30.77469 & Hannan-Quinn criter. & -1.507894 \\
F-statistic & 9.827228 & Durbin-Watson stat & & 2.606671 \\
Prob(F-statistic) & 0.000027 & & & \\
\hline \hline
\end{tabular}

Table 6. Regression model results

Source: authors' calculation using the Eviews statistical software

To interpret the results properly, initial assumptions had been tested too. The residuals met the assumption of normal distribution (Jarque-Bera $=0.039$; $\mathrm{p}$-value $=0.98$ ) Further, by calculating correlation coefficients, a problem of collinearity did not appear either by calculating the Pearson Correlation (all correlation coefficients were less than $\sqrt{R^{2}}=0.8141$ ) nor by calculating the Variance Inflation Factors (VIF $<3$ for all the independent variables). By running the Breusch-Godfrey Serial Correlation LM Test, the problem of autocorrelation had occurred $\left(\lambda^{2}=0.0057\right)$. Regarding the Durbin-Watson test, it can be concluded that there may be a possible problem of negative autocorrelation ( $\mathrm{DW}>2.3$ ). In this case, that problem was not considered significant, since the model had included a one-year period, not multiple time series. And finally, the heteroscedasticity had been tested using the Breusch-Pagan-Godfrey test $\left(\lambda^{2}=0,162\right)$ and the White test $\left(\lambda^{2}=0,569\right)$, where both tests showed that the problem of heteroscedasticity did not exist. Since all of the assumptions regarding the multiple linear regression model have been satisfied, the results can be interpreted.

The final regression model explains $59.53 \%$ of the variability of the response data. Together with F-statistics, the model could be considered to have a strong relationship with the response variable. After running the final model, nothing changed regarding the influence of the financial ratios and the auditor type variable. 
Even though the model increased its explanatory strength after excluding the control variables, all the main independent variables regarding the financial ratios stayed insignificant in explaining the ICDI. Not even the auditor type expressed any significant influence on the ICDI. The explanation of these results may be found in the generally low ICDI already presented in the previous chapter.

The only independent variable that had shown to have a statistically significant influence on ICDI was firm size. Accordingly, only the first hypothesis has been confirmed. The model presented in table 6 includes the firm size measured as either as a small, medium-sized, and large company. To test the influence of firm size, which is measured by total revenues and total asset, two more regression models had been run. Table 7 presents the results using the total assets as a measurement for the firm size.

\begin{tabular}{lrlrr}
$\begin{array}{l}\text { Dependent Variable: ICDI } \\
\text { Method: Least Squares } \\
\text { Included observations: } 31\end{array}$ & & & \\
\hline \hline & Coefficient & Std. Error & t-Statistic & Prob. \\
\hline \hline Cariable & -0.054102 & 0.050016 & -1.081686 & 0.2897 \\
SIZE_ASSET & $1.33 \mathrm{E}-09$ & $1.28 \mathrm{E}-10$ & 10.38763 & 0.0000 \\
AUDIT & 0.034488 & 0.027224 & 1.266801 & 0.2169 \\
ROE & -0.015791 & 0.013080 & -1.207315 & 0.2386 \\
LIQUID & 0.000849 & 0.006208 & 0.136789 & 0.8923 \\
LEVER & 0.087971 & 0.062509 & 1.407331 & 0.1716 \\
\hline \hline R-squared & 0.825446 & Mean dependent var & & 0.170323 \\
Adjusted R-squared & 0.790536 & S.D. dependent var & & 0.156960 \\
S.E. of regression & 0.071836 & Akaike info criterion & & -2.256864 \\
Sum squared resid & 0.129012 & Schwarz criterion & & -1.979318 \\
Log likelihood & 40.98139 & Hannan-Quinn criter. & & -2.166391 \\
F-statistic & 23.64451 & Durbin-Watson stat & & 2.735298 \\
Prob(F-statistic) & 0.000000 & & & \\
\hline
\end{tabular}

Table 7. Regression model results using total asset as a variable Source: authors' calculation using the Eviews statistical software

The influence of firm size calculated by the firm's total assets remains significant again, with a reliability level of $95 \%$. Using this approach, all independent variables, excluding the current liquidity ratio, became more significant even though none of them had shown a statistically significant influence on the ICDI. This time, the model is explained with a $79.05 \%$ accuracy, which is an increase of $32.79 \%$. And finally, table 8 presents the results using the total revenues as a measurement for the firm size. 
Dependent Variable: ICDI

Method: Least Squares

Included observations: 31

\begin{tabular}{lrlrr}
\hline \hline \multicolumn{1}{c}{ Variable } & Coefficient & \multicolumn{1}{c}{ Std. Error } & t-Statistic & Prob. \\
\hline \hline C & 0.037674 & 0.084455 & 0.446085 & 0.6594 \\
SIZE_REVENUES & $7.09 \mathrm{E}-10$ & $1.64 \mathrm{E}-10$ & 4.309612 & 0.0002 \\
AUDIT & 0.040092 & 0.047792 & 0.838885 & 0.4095 \\
ROE & -0.021797 & 0.023012 & -0.947216 & 0.3526 \\
LIQUID & 0.004616 & 0.010880 & 0.424235 & 0.6750 \\
LEVER & -0.035035 & 0.108401 & -0.323193 & 0.7492 \\
\hline \hline R-squared & 0.467588 & Mean dependent var & 0.170323 \\
Adjusted R-squared & 0.361106 & S.D. dependent var & 0.156960 \\
S.E. of regression & 0.125460 & Akaike info criterion & -1.141677 \\
Sum squared resid & 0.393504 & Schwarz criterion & -0.864132 \\
Log likelihood & 23.69600 & Hannan-Quinn criter. & -1.051204 \\
F-statistic & 4.391224 & Durbin-Watson stat & 2.291109 \\
Prob(F-statistic) & 0.005249 & & \\
\hline \hline
\end{tabular}

Table 8. Regression model results using total revenues as a variable

Source: authors' calculation using the Eviews statistical software

Even though this model had also shown a statistically significant influence of firm size on the disclosure index, the explanatory strength of it was the lowest compared to the other two models (only $36.11 \%$ ). The other independent variables had shown the lowest influence on the disclosure index too. In that sense, it could be concluded that the best model for measuring the influence of the firm size on the ICDI is the one that uses total assets as a measurement of firm size, followed by the actual firm size, taking into account all the categories used for firm-size categorization.

Given that most companies had disclosed less information regarding the IC than it was expected, one of the possible way to encourage them to note, follow, and compare the value of the IC and share the information with stakeholders will be given in the next chapter.

\section{The Impact of Balanced Scorecard in Systematic Monitoring of Defined Goals and Strategies}

Managers obtain a balanced and sustained vision of the main organizational perspectives by monitoring the four fundamental management perspectives, namely the financial, internal, customers', and the learning and growth perspective. The BSC is one of the most appropriate tools for strategic and performance measurement [65] being even considered a superior management tool [66], [67]. "Balanced scorecard is the most well-known and the most widely used approach of control and management 
rating by which the managing is observed from the perspective of financial performance, customer service, internal operational processes, and enterprise learning and growth capability through which the key performance indicators to be run by the company are identified [63]."

At the beginning of 2000, several organizations considered this tool crucial for monitoring strategy and organizational performance, as it is based not only on the financial (sales volume and profitability) but also on other perspectives. Despite being independent, these perspectives establish a cause-and-effect relationship among themselves [65] leading to an integrated system for measuring performance [68], as it assists organizations in not just measuring, but also achieving performance [69]. "The most important goal of this model is to leave the managing of the business exclusively to traditional financial indicators and emphasize the application of indicators related to the perspective of buyers, internal processes, and learning and growing, which are based on the vision and strategy of the business [23]."

Having these benefits in mind, all non-financial indicators play an important role in the organization's solvency [70]. The learning and growth perspective is the least prominent, although it holds the key to sustainability, and, consequently, employee training, information systems, as well as motivation, which are extremely important factors that should not be ignored [71]. In this sense, organizations should promote an organizational culture that fosters employees' willingness to participate and feel involved. While the financial, customer, and internal perspective could be successful for a business, it is crucial that employees are also qualified. Therefore, the learning and growth perspective needs to be leveraged to highlight the importance of human capital and information systems. The importance of learning and motivation is considered the key characteristic for an organization's success so that the competencies, productivity, and performance targets of the collaborators align with the objectives of the BSC [72]. Along the same train of thought, a study developed in Portugal indicated that organizations with BSC are more receptive to learning and growth [73]. Following the study, the learning and growth perspective is mainly seen in an organisation's capacity to learn, adapt, and grow. In this sense, the resources that the organization allocates to research and development, especially human resources, are extremely relevant for the organisation's success [74].

The BSC is primarily used for measuring performance, communicating both strategic goals and ways to achieve them [65], [71]. The BSC is a cooperative tool with a focus on development, communication, goal setting, and feedback, helping in strategic decisions by linking the goals to the organizational strategy, making the BSC a relevant management tool for companies to use to achieve their set goals [75]. BSC might be seen as a "vehicle" that helps companies in making breakthroughs [76], as it provides focused and useful information to managers [77]. Even organizations that had not yet implemented the BCS recognize that the BSC has the power to promote performance and strategy [78].

Strategy remains an art and should never be seen systematically, as the organization's objectives, which are based on the exhaustive analysis of the internal and external environment, define it, and that analysis helps companies identify opportunities and threats to the strategy itself [79]. Kaplan and Norton have developed 
hundreds of strategic maps to define their scorecards. They consider that the first step is to present a blank sheet, asking the client to define the concept of strategy on that sheet. Then, the strategic map and the BSC should be constructed based on interviews and discussions between process managers, who specify critical elements of the organizational strategy linkage, such as the following [70]: growth objectives, market share, definition of value, innovation, and investment.

The organizational strategy is then aligned on the strategic map to guide organizations in developing their areas of knowledge [80]. Given the broad applicability of the BSC and its relevance to non-industrial organizations, such as universities, the BSC recognizes the ability to connect vision, mission, strategies, and operational activities to set goals, objectives, and performance assessment [81].

All the above mentioned is also very important for high-tech companies. Taking into account their financial and non-financial perspectives can contribute to a better understanding of their business and achieving their goals.

\section{Conclusion}

Companies from all sectors are encouraged to disclose non-financial information not presented in the financial statements in order to give stakeholders as many information regarding their business operations as they can. There are many firm characteristics which may have an influence on reporting quality and its extent. Research results based on a sample of Croatian high-tech companies have shown a low level of disclosures when it comes to the disclosure of IC information. The only firm characteristic, which has shown a statistically significant positive influence on the amount of information disclosed was firm size. Neither auditor type nor financial ratios have shown a statistically significant influence, which can be explained by the overall low level of disclosures regarding the IC. Companies are encouraged to present additional information in order to give the complete picture of their business to the stakeholders.

\section{References}

[1] D. H. Luthy, "Intellectual capital and its measurement," presented at the Second Asian Pacific Interdisciplinary Research in Accounting Conference (APIRA), Osaka, Japan, 1998. [Online]. Available: https://pdfs.semanticscholar.org/ab31/a561613f45a9c1ee3805a5c9be6ad5d 1c031.pdf [Accessed: Apr. 12, 2019].

[2] P. H. Sullivan, Profiting from Intellectual Capital: Extracting Value from Innovation. Canada: John Wiley \& Sons, Inc., 1998.

[3] T. A. Stewart, "Your company's most valuable asset: intellectual capital," Fortune, October 3, pp. 68-74, 1994. [Online]. Available: http://archive.fortune.com/magazines/fortune/fortune_archive/1994/10/03/ 79803/index.htm [Accessed: Apr. 12, 2019]. 
[4] A. Bounfour and L. Edvinson, Intellectual Capital for Communities: Nations, Regions, and Cities. Burlington, USA: Elsesvier ButterworthHeinemann, 2005.

[5] I. Abeysekera, "The Project of Intellectual Capital Disclosure: Researching the Research," Journal of Intellectual Capital, vol. 7, no. 1, pp. 61-77, 2006.

[6] C. W. Choo and N. Bontis, The Strategic Management of Intellectual Capital and Organizational Knowledge. New York: Oxford University Press, 2002.

[7] N. Bontis, "Intellectual Capital: An exploratory study that develops measures and models," Management Decision, vol. 36, no. 2, pp. 63-76, 1998.

[8] K. E. Sveiby, "A knowledge-based theory of the firm to guide in strategy formulation," Journal of Intellectual Capital, vol. 2, no. 4, pp. 344-358, 2001.

[9] J. Guthrie, "The management, measurement and the reporting of intellectual capital," Journal of Intellectual Capital, vol. 2, no. 1, pp. 27$41,2001$.

[10] P. K. M'Pherson and S. Pike, “Accounting, empirical measurement and intellectual capital," Journal of Intellectual Capital, vol. 2, no. 3, pp. 246260, 2001.

[11] I. Rodov and P. Leliaert, "FiMIAM: financial method of intangible assets measurement," Journal of Intellectual Capital, vol. 3, no. 3, pp. 323-336, 2002.

[12] D. Andriessen, Making Sense of Intellectual Capital - Designing a Method for the Valuation of Intangibles. Amsterdam: Elsevier ButterworthHeinemann, 2004.

[13] J. Chen, Z. Zhu, and H. Y. Xie, "Measuring intellectual capital: a new model and empirical study," Journal of Intellectual Capital, vol. 5, no. 1, pp. 195-212, 2004.

[14] K. Gopika and G. A. Wilfried, "Intellectual capital: Measurement effectiveness," Journal of Intellectual Capital, vol. 5, no. 3, pp. 389-413, 2004.

[15] D. Sundać and I. Fatur Krmpotić, "Measurement and Management of Intellectual Capital," Tourism and Hospitality Management, vol. 15, no. 2, pp. 279-290, 2009. [Online]. Available: https://hrcak.srce.hr/64645

[Accessed: Apr. 22, 2019].

[16] Y. Todorova, E. Gourova, and D. Birov, "Measuring Knowledge Management and relation with Balanced Scorecard," in Proceedings of 
ICEIRD 2010, $3^{\text {rd }}$ International Conference for Entrepreneurship, Innovation and Regional Development, Novi Sad, Serbia, 739-745, 2010. [Online]. Available:

https://www.researchgate.net/publication/264094184_Measuring_Knowled ge_Management_and_relation_with_Balanced_Scorecard [Accessed: Apr. 22, 2019].

[17] A. Fritzsche, "Implicit Evaluations of Intellectual Capital in Practical Decision Making," The Electronic Journal of Knowledge Management, vol. 10, no. 3, pp. 236-243, 2012. [Online]. Available: http://www.ejkm.com/front/search/index.html [Accessed: Apr. 11, 2019].

[18] D. Yazdanfar, "Profitability determinants among micro firms: evidence from Swedish data," International Journal of Managerial Finance, vol. 9, no. 2, pp. 151-160, 2013.

[19] I. Oleynikova and Z. Balbaniuk, "Impact of Intellectual Capital Management and Human Capital Circulation on Business Practice at Macro- and Micro Level,” 2017. [Online]. Available: https://www.researchgate.net/publication/321416183 [Accessed: Apr. 22, 2019].

[20] N. Bontis, W. C. C. Keow, and S. Richardson, "Intellectual capital and business performance in Malaysian industries," Journal of Intellectual Capital, vol. 1, no. 1, pp. 85-100, 2000.

[21] D. Carlucci, B. Marr, and G. Schiuma, "The knowledge value chain: how intellectual capital impacts on business performance," International Journal of Technology Management, vol. 27, no. 6/7, pp. 575-590, 2004.

[22] M. C. Chen, S. J. Cheng, and Y. Hwang, "An empirical investigation of the relationship between intellectual capital and firms' market value and financial performance," Journal of Intellectual Capital, vol. 6, no. 2, pp. 159-176, 2005.

[23] K. Černe, "Strategic accounting system of monitoring and studying the intellectual capital," Unpublished Doctoral Dissertation. Pula, Croatia: Juraj Dobrila University of Pula, 2011.

[24] M. Turuk, "Influence of intellectual capital on the profitability of Croatian companies," International journal of management cases, vol. 15, no. 1, pp. 75-83, 2012.

[25] N. Nuryaman, "The Influence of Intellectual Capital on The Firm's Value with The Financial Performance as Intervening Variable," Procedia Social and Behavioral Sciences, vol. 211, no. 25, pp. 292-298, 2015.

[26] S. Muda and M. Ridhuan, "Intellectual Capital and Performance: a Study on Malaysian SMEs," In Proceedings of 8th International Economics and Business Management Conference, The European Proceedings of Social \& 
Behavioural Sciences, pp. 382-391, 2018. [Online]. Available:

https://www.researchgate.net/publication/326722719_Intellectual_Capital_ And_Performance_A_Study_On_Malaysian_Smes [Āccessed: Apr. 12, 2019].

[27] M. Khalique, N. Bontis, J. A. N. Bin Shaari, M. R. Yaacob, and R. Ngah, "Intellectual capital and organisational performance in Malaysian knowledge-intensive SMEs," International Journal of Learning and Intellectual Capital, vol. 15, no. 1, pp. 20-36, 2018.

[28] N. Bontis, "Intellectual Capital Disclosure in Canadian Corporations," Journal of Human Resource Costing \& Accounting, vol. 7, no. 1/2, pp. 920, 2003.

[29] S. Bozzolan, F. Favotto, and F. Ricceri, "Italian annual intellectual capital disclosure: An empirical analysis," Journal of Intellectual Capital, vol. 4, no. 4, pp. 543-558, 2003.

[30] M. J. Abdolmohammadi, "Intellectual capital disclosure and market capitalization," Journal of Intellectual Capital, vol. 6, no. 3, pp. 397-416, 2005.

[31] M. Joshi, D. Singh Ubha, and J. Sidhu, "Intellectual capital disclosures by Indian and Australian information technology companies: A comparative analysis," Journal of Intellectual Capital, vol. 13, no. 4, pp. 582-598, 2012.

[32] M. A. Boujelbene and H. Affes, "The impact of intellectual capital disclosure on cost of equity capital: A case of French firms," Journal of Economics, Finance and Administrative Science, vol. 18, no. 34, pp. 45-53, 2013.

[33] Q. Wang, U. Sharma, and H. Davey, "Intellectual capital disclosure by Chinese and Indian information technology companies: A comparative analysis," Journal of Intellectual Capital, vol. 17, no. 3, pp. 507-529, 2016.

[34] A. Rep, “Accounting Treatment of Intangible Assets - Analysis of Computer Programming Companies," International Journal of E-Services and Mobile Applications, vol. 11, no. 3, pp. 61-77, 2019.

[35] A. Brüggen, P. Vergauwen, and M. Dao, "Determinants of intellectual capital disclosure: evidence from Australia," Management Decision, vol. 47, no. 2, pp. 233-245, 2009.

[36] M. L. Bhasin, "Measurement and Disclosure of Intellectual Capital in a Developing Country: An Exploratory Study," Australian Journal of Business and Management Research, vol. 2, no. 8, pp. 63-75, 2012.

[37] Commission Regulation (EC) No 1126/2008 of 3 November 2008 adopting certain international accounting standards in accordance with Regulation (EC) No 1606/2002 of the European Parliament and of the Council. [Online]. Available: https://eur-lex.europa.eu/legal- 
content/EN/TXT/PDF/?uri=CELEX:32008R1126\&from=EN [Accessed: Apr. 12, 2019].

[38] I. Mamić Sačer and N. Dečman, "Accounting treatment of certain forms of intangible assets," Accounting and Finance, vol. 61, no. 5, pp. 18-20, 2015.

[39] Zakon o porezu na dobit. Narodne novine br. 177/04, 90/05, 57/06, 146/08, 80/10, 22/12, 148/13, 143/14, 50/16, 115/16, 106/18.

[40] I. Mamić Sačer, I. Pavić, and A. Rep, "Disclosure Practices and Perspectives of Notes to Financial Statements in Croatian Tourism Companies," In Khalid S. Soliman (Ed.), Proceedings of the 30th International Business Information Management Association Conference (IBIMA), Madrid, Spain, IBIMA Publishing, pp. 3859-3871, 2017. [Online]. Available: https://www.researchgate.net/publication/333245552 [Accessed: Apr. 12, 2019].

[41] K. E. Sveiby, "Methods for Measuring Intangible Assets," 2010. [Online]. Available: https://www.sveiby.com/files/pdf/intangiblemethods.pdf [Accessed: Apr. 11, 2019].

[42] K. Camfferman and T. E. Cooke, "An Analysis of Disclosure in the Annual Reports of U.K. and Dutch Companies," Journal of International Accounting Research, vol. 1, no. 1, 3-30, 2002.

[43] S. Singh Singhvi, "Corporate disclosure through annual reports in the United States of America and India," Journal of Finance, vol. 23. no, 3, pp. 551-552, 1968.

[44] S. Singh Singhvi and H. B. Desai, "An Empirical Analysis of the Quality of Corporate Financial Disclosure," The Accounting Review, vol. 46, no. 1, pp. 129-138, 1971.

[45] R. S. Olusegun Wallace, K. Naser, and A. Mora, "The Relationship between the Comprehensiveness of Corporate Annual Reports and Firm Characteristics in Spain," Accounting and Business Research, vol. 25, no 97, pp. 41-53, 1994.

[46] J. Guthrie, R. Petty, and F. Ricceri, "The voluntary reporting of intellectual capital: Comparing evidence from Hong Kong and Australia," Journal of Intellectual Capital, vol. 7, no. 2, pp. 254-271, 2006.

[47] G. White, A. Lee, and G. Tower, "Drivers of voluntary intellectual capital disclosure in listed biotechnology companies," Journal of Intellectual Capital, vol. 8, no. 3, pp. 517-537, 2007.

[48] L. Bellora and T. W. Guenther, "Drivers of innovation capital disclosure in intellectual capital statements: Evidence from Europe," The British Accounting Review, vol. 45, no. 4, pp. 255-270, 2013. 
[49] S. M. Williams, "Is intellectual capital performance and disclosure practices related?," Journal of Intellectual Capital, vol. 2, no. 3, pp. 192203, 2001.

[50] P. N. Bukh, C. Nielsen, P. Gormsen, and J. Mouritsen, "Disclosure of information on intellectual capital in Danish IPO prospectuses," Accounting, Auditing \& Accountability Journal, vol. 18, no. 6, pp. 713732, 2005.

[51] G. Rimmel, C. Nielsen, and T. Yosano, "Intellectual capital disclosures in Japanese IPO prospectuses," Journal of Human Resource Costing \& Accounting, vol. 13, no. 4, pp. 316-337., 2009.

[52] R. H. Whiting and J. Woodcock, "Firm characteristics and intellectual capital disclosure by Australian companies," Journal of Human Resource Costing \& Accounting, vol. 15, no 2, pp.102-126, 2011.

[53] A. L. Ferreira, M. C. Branco, and J. A. Moreira, "Factors influencing intellectual capital disclosure by Portuguese companies," International Journal of Accounting and Financial Reporting, vol. 2, no. 2, pp. 278-198, 2012.

[54] F. Depoers and T. Jeanjean, "Determinants of Quantitative Information Withholding in Annual Reports," European Accounting Review, vol. 21, no. 1, pp. 115-151, 2012.

[55] S. J. Lim, G. White, A. Lee, and Y. Yuningsih, "A longitudinal study of voluntary disclosure quality in the annual reports of innovative firms," Accounting Research Journal, vol. 30, no 1, pp. 89-106, 2017.

[56] D. G. Barako, "Determinants of voluntary disclosures in Kenyan companies annual reports," African Journal of Business Management, vol. 1, no. 5, pp. 113-128, 2007.

[57] K. E. Sveiby, “The Intangible Assets Monitor," Journal of Human Resource Costing \& Accounting, vol. 2, no. 1, pp. 73-97, 1997.

[58] J. Guthrie and R. Petty, "Intellectual capital: Australian annual reporting practices," Journal of Intellectual Capital, vol. 1, no. 3, pp. 241-251, 2000.

[59] J. Guthrie, R. Petty, K. Yongvanich, and F. Ricceri, "Using content analysis as a research method to inquire into intellectual capital reporting," Journal of Intellectual Capital, vol. 5, no. 2, pp. 282-293, 2004.

[60] R. Petty and S. Cuganesan, "Voluntary Disclosure of Intellectual Capital by Hong Kong Companies: Examining Size, Industry and Growth Effects Over Time," Australian Accounting Review, vol. 15, no. 36, pp. 40-50, 2008.

[61] G. White, A. Lee, Y. Yuningsih, C. Nielsen, and P. N. Bukh, "The nature and extent of voluntary intellectual capital disclosures by Australian and 
UK biotechnology companies," Journal of Intellectual Capital, vol. 11, no 4, pp. 519-536, 2010.

[62] A. Schneider and G. Samkin, "Intellectual capital reporting by the New Zealand local government sector," Journal of Intellectual Capital, vol. 9, no. 3, pp. 456-486, 2008.

[63] K. Žager, I. Mamić Sačer, S. Sever Mališ, A. Ježovita, and L. Žager, Analysis of financial statements - principles, procedures, cases. Third Revised Edition. Zagreb, Croatia: Association of Accountants and Financial Experts, 2017.

[64] B. Kamath, "Intellectual capital disclosure in India: content analysis of "TecK" firms," Journal of Human Resource Costing \& Accounting, vol. 12, no. 3, pp. 213-224, 2008.

[65] R. S. Kaplan and D. P. Norton, "The Balanced Scorecard - Measures That Drive Performance," Harvard Business Review, vol. 70, no. 1, pp. 71-79, 1992. [Online]. Available: https://hbr.org/1992/01/the-balanced-scorecardmeasures-that-drive-performance-2 [Accessed: Jun. 10, 2019].

[66] H. Norreklit, "The balance on the balanced scorecard a critical analysis of some of its assumptions," Management Accounting Research, vol. 11, no. 1, pp. 65-88, 2000.

[67] H. Norreklit, M. Jacobsen, and F. Mitchell, "Pitfalls in using the balanced scorecard," Journal of Corporate Accounting \& Finance, vol. 19, no. 6, pp. $65-68,2008$.

[68] I. Kerssens-van Drongelen, B. Nixon, and A. Pearson, "Performance Measurement in Industrial R\&D," International Journal of Management Reviews, vol. 2, no. 2, pp. 111-143, 2000.

[69] G. A. Neufeld, P. A. Simeoni, and M. A. Taylor, "High-Performance Research Organizations," Research Technology Management, vol. 44, no. 6., pp. 42-52, 2001.

[70] R. S. Kaplan and D. P. Norton, "Transforming the balanced scorecard from performance measurement to strategic management: Part 1," Accounting Horizons, vol. 15, no. 1, pp. 87-104, 2001.

[71] R. S. Kaplan and D. P. Norton, "Knowing the score," Financial Executive, vol. 12 , no. 6, pp. 30-33, 1996.

[72] D. Campbell, S. M. Datar, S. L. Kulp, and V. G. Narayanan, “Testing Strategy with Multiple Performance Measures Evidence from a Balanced Scorecard at Store24," Journal of Management Accounting Research, vol. 27, no. 2, pp. 39-65, 2015.

[73] C. Oliveira, J. Pinho, and A. Silva, "The relevance of learning and growth in organizations that adopt and do not adopt the bsc- characterization of the 
cultural profile," Revi Sta Eletrônica Gestão \& Sociedade, vol. 12, no. 33, pp. 2584-2602, 2018.

[74] T. García-Valderrama, E. Mulero-Mendigorri, and D. Revuelta-Bordoy, “A Balanced Scorecard framework for R\&D," European Journal of Innovation Management, vol. 11, no. 2, pp. 241-281, 2008.

[75] G. Wegmann, "The balanced scorecard as a knowledge management tool: a French experience in a semi-public insurance company," Journal of Knowledge Management, vol. 6, no. 3, pp. 22-38, 2008.

[76] H. Atkinson, "Strategy implementation: a role for the balanced scorecard?," Management Decision, vol. 44, no. 10, pp. 1441-1460, 2006.

[77] J. Strohhecker, "Factors influencing strategy implementation decisions: an evaluation of a balanced scorecard cockpit, intelligence, and knowledge," Journal of Management Control, vol. 27, no. 1, pp. 89-119, 2016.

[78] C. Oliveira, Balanced Scorecard, Organizational Culture and Performance: The Case of the Mayor Export Companies in Portugal, Unpublished Doctoral Dissertation. Braga, Portugal: University of Minho, 2018.

[79] R. S. Kaplan and D. P. Norton, "Mastering the Management System," Harvard Business Review, Vol. 86 No. 1, pp. 62-77, 2008. [Online]. Available: https://hbr.org/2008/01/mastering-the-management-system [Accessed: Jun. 10, 2019].

[80] H. Hamid Hawass, "Exploring the determinants of the reconfiguration capability: a dynamic capability perspective," European Journal of Innovation Management, vol. 13, no. 4, pp. 409-438, 2010.

[81] J. Fijałkowska and C. Oliveira, "Balanced Scorecard in Universities," Journal of Intercultural Management, vol. 10, no. 4, pp. 57-83, 2018. 